\section{Sensitive determination of impurities in samples of vodka by gas chromatography with flame-ionization detection}

\author{
Baimatova N.Kh. ${ }^{*}$, Demyanenko O.P. \\ Ahmad Zia \\ Center of Physical Chemical Methods of \\ Research and Analysis, \\ l-Farabi Kazakh National University, \\ Almaty, Kazakhstan \\ *E-mail: baimatova.nassiba@gmail.com
}

Vodka is one of the most popular alcoholic drinks around the world. Adulteration of vodkas lead to many negative consequences. A number of analytical methods covers a wide range of analytes and allows detection of adulterated alcoholic beverages, however, most of these methods are very labor and time consuming or require expensive analytical instrumentation. The simplest and thus most popular method is based on direct analysis by gas chromatography (GC) with flameionization detection (FID). The main drawback of this method for discovery of adulterated vodka samples is insufficient sensitivity. The aim of this study was to increase sensitivity of the method for determination of key vodka impurities. Optimized parameters included split ratio 10:1, inlet temperature $>120^{\circ} \mathrm{C}$, initial oven temperature $60^{\circ} \mathrm{C}$, flow rates of make-up gas, air and hydrogen 50,400 and $40 \mathrm{~mL} / \mathrm{min}$, respectively. Obtained calibration plots are linear in the concentration range between 1 and $1000 \mathrm{mg} / \mathrm{L}$ with approximation coefficients $\mathrm{R}^{2}>0.99$. Compared to a standard method, slope factors are about 4 times higher when optimized method is used proving its higher sensitivity. teration.

Keywords: gas chromatography; flame ionization detector; analysis; vodka; impurities; adulration.

\section{Арақ үлгілерің \\ құрамындағы негізгі микроқоспаларды жалынды- ионизациялайтын детекторымен газды хроматография әдісімен сезімталды анықтау}

Байматова Н.Х. , Демьяненко О.П. Ахмад Зия

Физика-химиялық зерттеу және талдау орталығы әл-Фараби атындағы Қазақ ұлттық университеті, Алматы қ., Қазақстан *E-mail: baimatova.nassiba@gmail.com
Арақ дүние жүзінде ең кең тараған алкоголь ішімдігі болып табылады. Арақть бұрмалау көптеген кері әсерін тигізеді. Аналитикалық әдістердің көбі анықталатын заттардың кең ауқымын анықтауға және бұрмаланған алкогольді ішімдіктерді анықтауға мүмкіндік береді. Алайда, осы әдістердің көбі еңбексыйымдылығы жоғары, көп уақытты және қымбат аналитикалық құрал-жабдықтарды қажет ететін болып табылады. Ең қарапайым және кең тараған әдіс үлгіні жалынды-ионизациялайтын детекторымен жабдықталған газды хроматографтың үлгі енгізетін құрылғысына тура енгізуге негізделген. Арақтың бұрмаланған үлгілерін анықтау әдісінің негізгі кемшілігі - төмен сезімталдығы. Осы зерттеу жұмысының мақсаты - арақ үлгілерінде негізгі микроқоспаларды анықтау әдісінің сезімталдығын жоғарлату. Келесі параметрлер оңтайландырылған: ағын қатынасы - 10:1, үлгіні енгізу температурасы - $>120^{\circ} \mathrm{C}$, пештің бастапқы температурасы $-60^{\circ} \mathrm{C}$, ағынды газ, ауа және сутегі ағындарының жылдамдықтары - сәйкесінше, 50, 400 және 40 мл/мин. Алынған калибрлеу тәуелділіктері концентрациялардың 1-1000 мг/л аймағында аппроксимация коэффициент $\mathrm{R}^{2}>0,99$ болып, сызықты болып келеді. Стандартты әдіске қарағанда, анықтау шектері төрт есе жоғарлады.

Түйін сөздер: газды хроматография; жалынды-ионизациялайтын детектор; арақ; қоспалар.

\section{Чувствительное определение микропримесей в образцах водок методом газовой хроматографии с пламенно-ионизационным детектором}

Байматова Н.Х. ", Демьяненко О.П., Ахмад Зия

Центр физико-химических методов исследования и анализа, Казахский национальный университет имени аль-Фараби, г. Алматы, Казахстан *E-mail: baimatova.nassiba@gmail.com
Водка является одним из самых популярных алкогольных напитков во всем мире. Фальсификация водок приводит к многочисленным негативным последствиям. Ряд аналитических методов охватывают широкий спектр аналитов и позволяют обнаружение фальсифицированных алкогольных напитков, однако, большинство из этих методов трудоемки и занимают много времени и требуют дорогих аналитических приборов. Самый простой и наиболее распространенный метод основан на прямом вводе образца в устройство для ввода пробы газового хроматографа (ГХ) с пламенно-ионизационным детектором (ПИД). Основным недостатком этого метода обнаружения фальсифицированных образцов водки является недостаточная чувствительность. Целью данного исследования было увеличить чувствительность метода для определения основных микропримесей в образцах водок. Оптимизированы следующие параметры: деление потока - 10:1, температура ввода пробы $>120^{\circ} \mathrm{C}$, начальная температура печи $60^{\circ} \mathrm{C}$, скорости подачи поддувочного газа, воздуха и водорода 50, 400 и 40 мл/мин, соответственно. Полученные калибровочные зависимости линейной в всем диапазоне концентраций от 1 до 1000 мг/л с коэффициентами аппроксимации $R^{2}>0,99$. По сравнению со стандартным методом, угол наклона в 4 раза выше оптимизированной методикой.

Ключевые слова: газовая хроматография; пламенно-ионизационный детектор; водка; примеси 

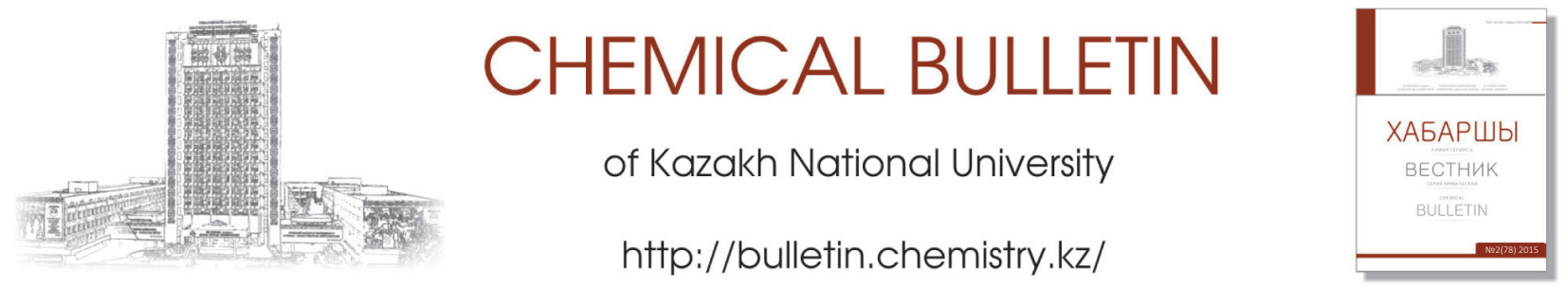

\title{
Sensitive determination of impurities in samples of vodka by gas chromatography with flame-ionization detection
}

\author{
Baimatova N.Kh.*, Demyanenko O.P., Ahmad Zia \\ Center of Physical Chemical Methods of Research and Analysis, \\ al-Farabi Kazakh National University, Almaty, Kazakhstan \\ *E-mail: baimatova.nassiba@gmail.com
}

\section{Introduction}

According to International Wines and Spirits Record (IWSR) [1], vodka is one of the most popular alcoholic drinks around the world. In 2012, 4.5 billion liters of vodka were drunk in world. Half of that amount was drunk in Russia (13.9 liters per capita). In Belarus, average citizen drunk 11.3 liters of vodka a year. Every citizen of Kazakhstan accounted for 5.9 liters of vodka a year [2].

Vodka is a colorless alcoholic beverage having characteristic spirituous odor and consisting from ethanol and water. Concentration of ethanol is normally $40 \%$, but it may also reach $56 \%$ in different countries depending on state regulatory requirements for vodka quality. Most vodkas are produced by a fermentation and a distillation of grains with subsequent filtration through charcoal or carbon filters. From the chemical point of view, vodkas are the purest alcoholic beverages.

According to independent experts, $46 \%$ of vodkas in markets are adulterated (counterfeit). Counterfeit vodka is mostly produced from poor-quality raw materials. Such vodkas are often illegally sold under known brands of vodka.

Consequences of the using of this "counterfeits" are unpredictable: from strong hangover to disability and death. Vodka refers to the most commonly adulterated group of alcoholic beverages. Therefore it is very important to discover and prevent it's adulteration. Laboratory analyses of vodka is the most efficient and reliable method for disclosing adulterated samples.

The presence of a number of impurities, e.g., acetone, is often associated with the use of synthetic ethanol.
Normally such alcohol have different "burning" smell and taste. In accordance with the Law of the Republic of Kazakhstan [3], the quality of alcoholic beverages as an industrial product should comply with the request of the public or industry standard according to certain parameters, that are responsible for its quality. Noncompliance with GOST-standard [4], [5] indicates artisanal beverage production. However, there are cases where counterfeit drinks correspond to standard parameters. This is because parameters of GOSTs have a wide range of values, some parameters limit total concentrations of a class of substances (such as fusel oils). Concentrations of many compounds are not limited by standards. Thus, the definition of the correspond parameters to the values of GOSTs is necessary but not sufficient condition for the study of adulterated alcohol products, which makes it necessary to develop, implement and continuously updated method to reflect advances in science and technology.

A number of analytical methods (Table 1 ) covers wide range of analytes and allows detection of adulterated alcoholic beverages. However, most of these methods are very labor and time consuming or require expensive analytical instrumentation.

The most popular methods for determining impurities in vodka based on GC-FID [4], [5] This method is standardized in former USSR countries including Kazakhstan. GOST R 51786-2001 and GOST R 516982000 methods are based on direct sample injection into GC inlet. These methods work well on samples having high concentrations of impurities (>10 mg/L). However, development of technology made it easier and cheaper 
Sensitive determination of impurities in samples of vodka by gas chromatography...

Table 1 - Methods of analysis of alcohol used in the detection of falsified objects

\begin{tabular}{|c|c|c|c|c|}
\hline$\#$ & Method & Objects & Determined compounds & Ref \\
\hline 1 & $\begin{array}{l}\text { GC-FID, capillary } \\
\text { column }\end{array}$ & $\begin{array}{l}\text { Alcohols, vodkas, } \\
\text { cognacs, rums, wines }\end{array}$ & $\begin{array}{l}\text { Ethanol, trace impurities: ethyl acetate, methanol, } \\
\text { n-propanol, iso-butanol, n-butanol, isoamylol alcohol }\end{array}$ & [6] \\
\hline 2 & $\begin{array}{l}\text { GC-FID, capillary } \\
\text { column }\end{array}$ & $\begin{array}{l}\text { Factory and home- } \\
\text { made alcoholic drinks } \\
\text { (home-brewed beer, } \\
\text { chacha, arrack) }\end{array}$ & $\begin{array}{c}\text { a. Ethanol, trace impurities: ethyl acetate, methanol, } \\
\text { n-propanol, iso-butanol, n-butanol, isoamylol alcohol. } \\
\text { b. Sugar: (trimethylsilyl derivatives) }\end{array}$ & [7] \\
\hline 3 & $\begin{array}{l}\text { GC-thermionic } \\
\text { detector }\end{array}$ & $\begin{array}{l}\text { Factory and home- } \\
\text { made alcoholic drinks } \\
\text { (home-brewed beer, } \\
\text { chacha, arrack) }\end{array}$ & $\begin{array}{l}\text { Allyl oil in wine (by identification and determination of } \\
\text { allyl isocyanate - a main component, whose purity is } \\
\qquad 95 \%)\end{array}$ & [7] \\
\hline 4 & GC-FID & Cognacs, vodkas & $\begin{array}{c}\text { Acetaldehyde, ethyl formate, ethyl acetate, methanol, } \\
\text { 2-butanol, n-propanol, iso-butanol, n-butanol, isoamyl } \\
\text { alcohol. } \\
\text { Caffeine from tea used for coloring falsification. }\end{array}$ & {$[8]$} \\
\hline 5 & $\begin{array}{l}\text { GC-FID, } \\
\text { GC-MS/MS, GC-MS, } \\
\text { ICP-MS }\end{array}$ & $\begin{array}{l}\text { Samohon, cheapest } \\
\text { vodka, medical liquids }\end{array}$ & $\begin{array}{l}\text { Methanol, acetaldehyde, higher alcohols, ethyl } \\
\text { carbamate, anions, and inorganic elements. } \\
\text { Data was compared to acceptable daily intake }\end{array}$ & [9] \\
\hline 6 & IR, ICP/MS, GC/FID & Artisanal alcohol, cuxa & $\begin{array}{l}\text { methanol, acetaldehyde, 1-propanol, 1-butanol, } \\
\text { 2-butanol, iso-butanol, } \\
\text { 2-/3-methyl-1-butanol and ethyl acetate, metals }\end{array}$ & [10] \\
\hline 7 & NIR Spectroscopy & $\begin{array}{l}\text { Whiskey, brandy, rum } \\
\text { and vodka }\end{array}$ & $\begin{array}{l}\text { Whole spectra of compounds; } \\
\text { PCA, SIMCA }\end{array}$ & [11] \\
\hline 8 & $\begin{array}{l}\text { Flow injection analysis } \\
\text { with photometric } \\
\text { detector }\end{array}$ & $\begin{array}{l}\text { Brandies, cachacas, } \\
\text { rums, whiskies and } \\
\text { vodkas }\end{array}$ & Schlieren effect, SIMCA & {$[12]$} \\
\hline
\end{tabular}

to produce adulterated alcoholic samples having low concentration of impurities being determined. In addition, these samples may be produced chemically, not from natural raw material (e.g. wheat, grape, etc.), that is illegal according to legislation.

Standard methods often do not provide sufficient sensitivity for the determination of trace impurities in highly pure vodka samples thus making differentiation and solution of forensic task impossible. In connection with this, the goal of present work was to increase sensitivity of standard methods for determination of trace impurities in vodka by GC-FID.

The aim of this study was to optimize GC-FID method for sensitive determination of vodka impurities.

\section{Experimental}

\subsection{Chemicals}

For analysis, the following pure substances (purity $>98 \%$ ) were taken: acetone, ethyl acetate, methanol, 2-butanol, 1-propanol, iso-butanol, isoamyl alcohol and 1-pentanol. Purity of these substances was established by their direct injection to 6890N/5973N GC-MS (Agilent,
USA). Helium (99.995\%) was purchased from "Tehgas" (Orenburg, Russia).

2.2 Vodka standard solution for method optimization For analysis, $1 \mathrm{~mL}$ of a standard solution of acetone, ethyl acetate, methanol, 2-butanol, 1-propanol, iso-butanol, isoamyl alcohol, 1-pentanol with concentration 10 $\mathrm{mg} / \mathrm{L}$ of each compound were prepared. Pure substances were dissolved in $40 \%$ ethanol solution "that was proven by GC-FID to be free of impurities. Vials were placed into the 7683 (Agilent, USA) autosampler tray for further analysis by gas chromatography with flame ionization detector 6890N (Agilent, USA).

2.3 Analysis by gas chromatography with flame ionization detection

All samples were analyzed on $6890 \mathrm{~N} / 5973 \mathrm{~N}$ (Agilent, Santa Clara, USA) gas chromatograph with mass spectrometric and flame ionization detectors equipped with split/splitless inlets. For separation of impurities, 0.5$1 \mu \mathrm{L}$ of the sample was injected into GC inlet. Separation was performed using a $50 \mathrm{~m} \times 0.32 \mathrm{~mm}$ HP-FFAP capillary column having film thickness of 0.5 micron under constant flow of helium $1 \mathrm{~mL} / \mathrm{min}$. Duration of the analysis depended on the number of determined impurities (20 to 
45 minutes). Other method parameters were optimized for an increased sensitivity. All experimental samples were analyzed in triplicates.

\subsection{Optimization of split ratio}

The experiment was carried out by varying the split ratio: $10: 1,15: 1,20: 1,30: 1,40: 1$ and 50:1. One $\mu \mathrm{L}$ of sample was injected directly into GC inlet heated to temperature $200^{\circ} \mathrm{C}$. Gas saver was activated $1 \mathrm{~min}$ after injection. Oven temperature was programmed from $60^{\circ} \mathrm{C}(10 \mathrm{~min})$ to $100^{\circ} \mathrm{C}$ (10 $\mathrm{min}$ ) at a heating rate of $20^{\circ} \mathrm{C} / \mathrm{min}$.

\subsection{Optimization of inlet temperature}

One $\mu \mathrm{L}$ of prepared sample was injected into GC inlet in 20:1 split mode at the following inlet temperatures: $120,140,160,180,200,220,240$ and $250^{\circ} \mathrm{C}$. Oven temperature was programmed from $60^{\circ} \mathrm{C}(10 \mathrm{~min})$ to $100^{\circ} \mathrm{C}(10 \mathrm{~min})$ at a heating rate of $20^{\circ} \mathrm{C} / \mathrm{min}$.

\subsection{Optimization of initial oven temperature}

According to manufacturer's specifications, working range of a column lies between 60 and $240^{\circ} \mathrm{C}$. The following initial oven temperatures were studied: 40, 50, 60, 70 and $80^{\circ} \mathrm{C}(10 \mathrm{~min})$ to $100^{\circ} \mathrm{C}(10 \mathrm{~min})$ at a heating rate of $20^{\circ} \mathrm{C} / \mathrm{min}$. One $\mu \mathrm{L}$ of samples were injected directly into $\mathrm{GC}$ inlet at $120^{\circ} \mathrm{C}$ and $20: 1$ split ratio.

\subsection{Optimization of FID make-up flow rate}

The following make-up flow rates were studied: 10 , $20,30,40,50$ and $60 \mathrm{~mL} / \mathrm{min}$. One $\mu \mathrm{L}$ of sample was injected directly into $\mathrm{GC}$ inlet at $120^{\circ} \mathrm{C}$ in $20: 1$ split mode. Oven temperature was programmed from $60^{\circ} \mathrm{C}(10 \mathrm{~min})$ to $100^{\circ} \mathrm{C}(10 \mathrm{~min})$ at a heating rate of $20^{\circ} \mathrm{C} / \mathrm{min}$.

\subsection{Optimization of air flow rate}

The following air flow rates were studied: 300, 400, 500 and $600 \mathrm{~mL} / \mathrm{min}$. One $\mu \mathrm{L}$ of sample was injected directly into $\mathrm{GC}$ inlet at $12{ }^{\circ} \mathrm{C}$ in $20: 1$ split mode. Oven temperature was programmed from $60^{\circ} \mathrm{C}(10 \mathrm{~min})$ to $100^{\circ} \mathrm{C}(10 \mathrm{~min})$ at a heating rate of $20^{\circ} \mathrm{C} / \mathrm{min}$. Run time was 22 minutes.

\subsection{Optimization of hydrogen flow rate}

The following hydrogen flow rates were studied: 40, 60 and $80 \mathrm{~mL} / \mathrm{min}$. One $\mu \mathrm{L}$ of sample was injected directly into $\mathrm{GC}$ inlet at $120^{\circ} \mathrm{C}$ in 20:1 split mode. Oven temperature was programmed from $60^{\circ} \mathrm{C}(10 \mathrm{~min})$ to $100^{\circ} \mathrm{C}(10 \mathrm{~min})$ at a heating rate of $20^{\circ} \mathrm{C} / \mathrm{min}$. Run time was 22 minutes.

2.10 Calibration of GC-FID by using optimized parameters

For calibration, the following pure substances (purity $>98 \%$ ) were taken: acetone, ethyl acetate, methanol, 2-butanol, 1-propanol, iso-butanol, isoamyl alcohol and 1-pentanol. Purity of these substances was established by their direct injection to 6890 N/5973N GCMS (Agilent, USA).

On the first stage, $10 \mathrm{~mL}$ of $40 \%$ ethanol solution in water not containing target analytes was introduced into a $10 \mathrm{~mL}$ vial. Then, $10.0 \mathrm{mg}$ of each analytes were injected into the vial using $25 \mu \mathrm{L}$ syringe (Agilent, Australia). Concentrations of analytes in the prepared solution made
Table 2 - The list of studied vodkas

\begin{tabular}{|c|c|c|}
\hline \# & Sample name & Sample origin \\
\hline 1 & Russkiy standart & Russia \\
\hline 2 & Khlebnaya dusha & Russia \\
\hline 3 & Yeni Raki & Turkey \\
\hline 4 & Rodnaya Derevenskaya & Russia \\
\hline 5 & Tri reki & Russia \\
\hline 6 & Khaoma gold & Kazakhstan \\
\hline 7 & Khaoma origin & Kazakhstan \\
\hline 8 & Ladoga Khlebnaya & Russia \\
\hline 9 & Moy gorod Semey & Kazakhstan \\
\hline 10 & Jelzin & France \\
\hline 11 & Russkaya marka & Russia \\
\hline 12 & Dikiy gus & Russia \\
\hline 13 & Belenkaya zolotaya & Russia \\
\hline 14 & Classic Rzhanaya & Russia \\
\hline 15 & Finka & Russia \\
\hline 16 & Khaoma Yubileynnaya & Kazakhstan \\
\hline 17 & Gramulka & Russia \\
\hline 18 & Kara Zhorga & Russia \\
\hline 19 & Casino & Russia \\
\hline 20 & Medovukha & Russia \\
\hline 21 & Syktyvkarskaya & Russia \\
\hline 22 & Rusitsa & Russia \\
\hline 23 & Vivat & Russia \\
\hline 24 & Arassa Aragy & Kazakhstan \\
\hline 25 & Zero $_{3}$ & USA \\
\hline
\end{tabular}

up $1000 \mathrm{mg} / \mathrm{L}$. The prepared solution was subsequently diluted to concentrations of analytes 1.0, 3.0, 5.0, 10.0, 30.0, 50.0, 100.0, 300.0, 500.0 and $1000.0 \mathrm{mg} / \mathrm{L}$. Every solution was prepared in triplicates. All prepared samples were analyzed on Agilent 6890N GC-FID at the optimized parameters and parameters given in GOST R 51786-2001 method.

Obtained chromatograms were integrated. Peaks were identified using previously established retention times of single analytes. Calibration dependences were plotted using MSD ChemStation software (version E.02.02 Service pack 1) and double-checked using MS Excel software.

\subsection{Application of the optimized method}

The optimized method was applied on 26 vodka samples (Table 2) purchased in shops in Kazakhstan (Almaty, Shymkent, Semipalatinsk), Turkey (Istanbul) and USA (Ames, lowa). 


\section{Results and Discussions}

\subsection{Optimization of split ratio}

Split ratio is most important parameter affecting method sensitivity. Its increase leads to the decrease of amount of analytes introduced into the column. For highest sensitivity, splitless injection should be used. However, in this case, we deal with samples containing $60 \%$ of water being undesirable in the column. Injection in splitless mode or at low split ratios may potentially lead to problems with column lifetime, analytes peaks shape and efficiency of resolution.

The goal of this experiment was to establish the effect of split ratio on analytes response and peak shape. Column lifetime is difficult and expensive to estimate and it was excluded from list of dependent variables.

The increase of split ratio (the injected volume of sample) leads to the proportional decrease of peak area (Figure 1). Maximum total peak area was observed at split ratio 10:1, which was selected as optimal.

\subsection{Optimization of inlet temperature}

Increase of inlet temperature is required to achieve fast and efficient introduction of analytes into the column. However, it can also facilitate chemical reactions between analytes and lead to problems with quantification. The goal of this experiment was to determine optimal injection port temperature.

The increase of inlet temperature leads to the decrease of responses of all analytes except acetone and methanol (Figure 2). Highest impact is observed for ethyl acetate response of which decreased by $25 \%$ at the increase of temperature from 120 to $240^{\circ} \mathrm{C}$. Decrease of response may be caused by degradation of analytes due to excessive temperature. Thus, the inlet temperature $120^{\circ} \mathrm{C}$ was selected as optimal.

\subsection{Optimization of initial oven temperature}

Initial oven temperature significantly affects peak shapes of volatile analytes and efficiency of their separation. Decrease of initial oven temperature may help to reconcentrate analytes in the front of a column thus improving peak shapes. It is especially helpful when splitless injection is used.

The goal of this experiment was to establish the optimal initial oven temperature for separation of vodka impurities on a $50 \mathrm{~m} \times 0.32 \mathrm{~mm}$ HP-FFAP (film thickness $0.50 \mu \mathrm{m}$ ) at the constant flow rate of carrier gas (helium grade " $A$ ") of $1 \mathrm{~mL} / \mathrm{min}$.

According to manufacturer's specifications, working range of a column lies between 60 and $240^{\circ} \mathrm{C}$. The following initial oven temperatures were studied: 40, 50, 60,70 and $80^{\circ} \mathrm{C}(10 \mathrm{~min})$ to $100^{\circ} \mathrm{C}(10 \mathrm{~min})$ at a heating rate of $20^{\circ} \mathrm{C} / \mathrm{min}$. One $\mu \mathrm{L}$ of samples were injected directly into GC inlet at $120^{\circ} \mathrm{C}$ and $20: 1$ split ratio. Sample was analyzed in 3 replicates for each initial oven temperature. Chromatograms were integrated, peaks were identified,

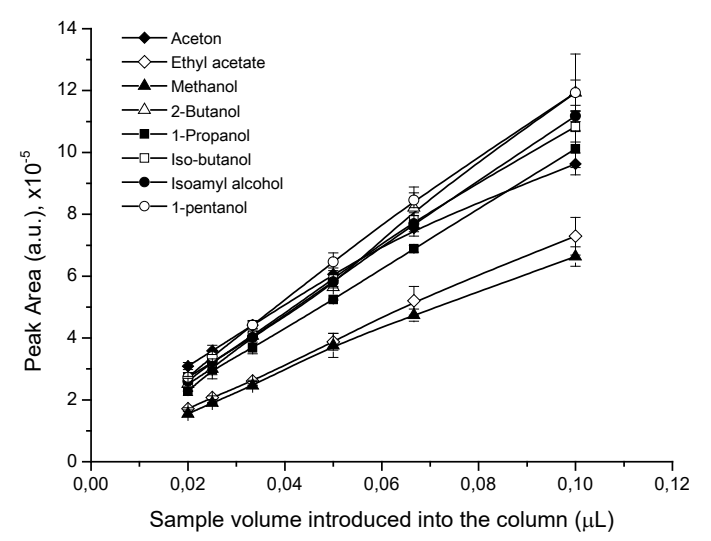

Figure 1 - Effect of the injected volume of sample on the peak area of vodka impurities

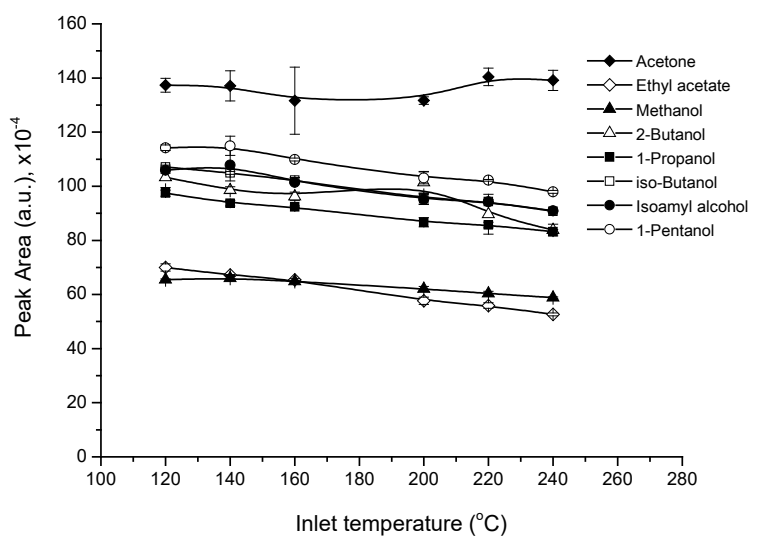

Figure 2 - Effect of the inlet temperature on peak area of impurities

areas of each peak and RSDs of each compound were calculated.

Change of oven temperature virtually does not lead to any change of responses of most analytes. Only responses of ethyl acetate and methanol decrease at 70-80 ${ }^{\circ} \mathrm{C}$ probably due to their poor retention at these temperatures (Figure 3). Initial oven temperature $60{ }^{\circ} \mathrm{C}$ was selected as optimal. In a case of problems with separation of methanol and ethyl acetate, this temperature may be decreased to $50^{\circ} \mathrm{C}$.

\subsection{Optimization of FID make-up flow rate}

Make-up gas is necessary in FID to increase flow rate through detector and decrease peak width. However, excessive increase of make-up flow may lead to decrease of response due to dilution of the flow eluting from the column. In addition, it may lead to excessive consumption of expensive high-grade helium. According to manufacturer, recommended make-up flow rate is $50 \mathrm{~mL} /$ $\min$ (Table 3), but standard methods require $40 \mathrm{~mL} / \mathrm{min}$. The goal of this experiment was to establish the optimal flow rate providing highest sensitivity for detection of vodka impurities by GC-FID.

Increase of a make-up gas flow rate leads to the increase of peak areas of all analytes (Figure 4). Maximum 




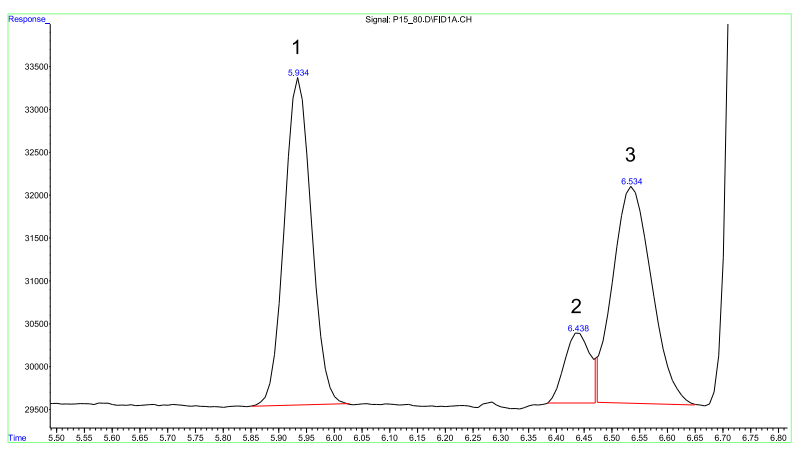

b

Figure 3-GC-FID chromatograms of impurities in vodka standard obtained at initial oven temperatures $60^{\circ} \mathrm{C}(\mathrm{a})$ and $80^{\circ} \mathrm{C}$ (b): 1 - acetone, 2 - ethyl acetate, 3 -methanol

increase of response at the increase of make-up flow from 10 to $50 \mathrm{~mL} / \mathrm{min}$ was observed for acetone $-40 \%$; for other compounds, the difference was $15-20 \%$. Because the difference of analytes responses between 50 and 60 $\mathrm{mL}$ is insignificant, $50 \mathrm{~mL} / \mathrm{min}$ was selected as optimal.

The goal of next two experiments was to optimize flow rates of air and hydrogen in FID. According to manufacturer's specifications, 450 and $40 \mathrm{~mL} / \mathrm{min}$ are optimal flow rates of air and hydrogen, respectively (Table 3). Increase of flow rates of these gases may potentially lead to a better efficiency of ionization of analytes, especially at higher concentrations. However, excessive flow of these gases may lead to dilution of gas eluted from the column and decrease of analytes response. In addition, it may lead to increase of consumption of gases and decreased lifespan of hydrogen and zero air generators.

\subsection{Optimization of air flow rate}

Air flow rate does not affect peak areas of vodka impurities. Therefore, flow rate recommended by the manufacturer ( $400 \mathrm{~mL} / \mathrm{min}$ ) was selected as optimal.

\subsection{Optimization of hydrogen flow rate}

Increase of hydrogen flow rate decreases peak areas of analytes (Figure 5). It may be caused by the decrease of ionization efficiency due non-stoichiometric ratio with

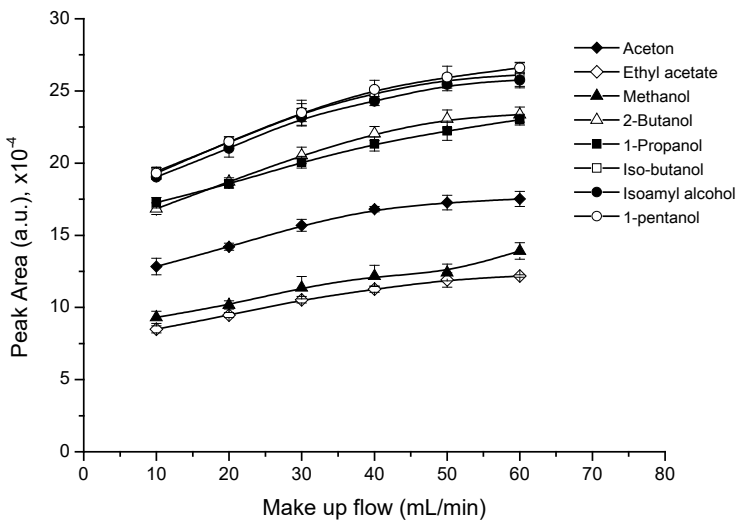

Figure 4 - Effect of a make-up gas flow rate on peak area of vodka impurities
Table 3 - Recommended flow rates for Agilent 6890 FID

\begin{tabular}{|l|c|c|}
\hline Detector gases & $\begin{array}{c}\text { Flow range, } \\
\mathrm{mL} / \mathrm{min}\end{array}$ & $\begin{array}{c}\text { Recommended } \\
\text { flow, } \mathrm{mL} / \mathrm{min}\end{array}$ \\
\hline Hydrogen & 0 to 100 & 40 \\
\hline Air & 0 to 800 & 450 \\
\hline $\begin{array}{l}\text { Column capillary } \\
\text { make up } \\
\begin{array}{l}\text { Recommended: } \\
\text { nitrogen } \\
\text { Alternate: helium }\end{array}\end{array}$ & 0 to 100 & 50 \\
\hline
\end{tabular}

air and dilution of gas eluted from the column. Thus, hydrogen flow rate $40 \mathrm{~mL} / \mathrm{min}$ was selected as optimal.

\subsection{Calibration using optimized parameters}

Obtained calibration plots are linear in the whole studied concentration range with approximation coefficients $R^{2}>0.99$ (Table 4). Compared to standard method, slope factors are about 4 times higher when optimized method is used proving its higher sensitivity.

Similar calibration plots were obtained using 6850 GC-FID (Agilent, USA) in Almaty Institute of Forensic Expertise (Table 5). Slope factors were also 4 times higher when using optimized method.

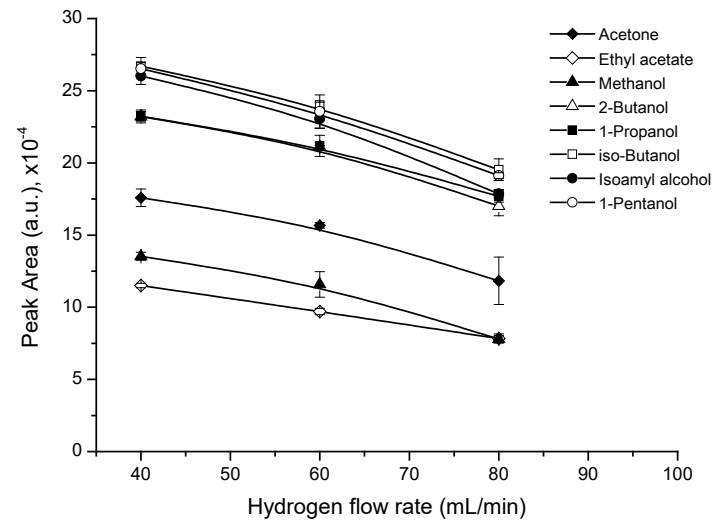

Figure 5 - Effect of the hydrogen flow rate on peak area of impurities 


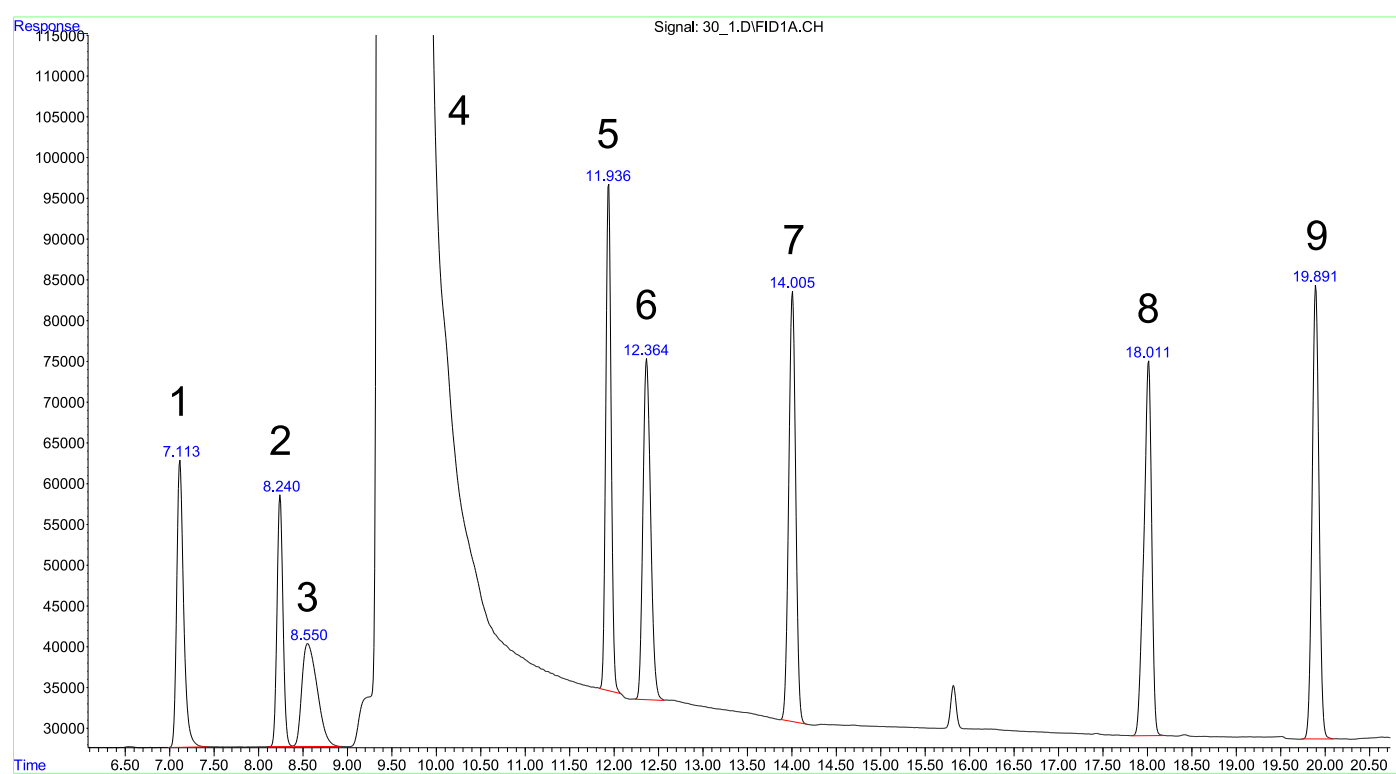

Peaks: 1 - acetone; 2 - ethyl acetate; 3 - methanol; 4 - ehanol; 5 - 2-butanol; 6 - 1-propanol; 7 - iso-butanol; 8 - isoamyl alcohol; 9 -1-pentanol; C $=30 \mathrm{mg} / \mathrm{L}$

Figure 6 - GC-FID chromatograms of vodka standard obtained by the optimized method

Table 4 - Results of calibration using optimized method in comparison with standard method

\begin{tabular}{|c|c|c|c|c|c|}
\hline \multirow{2}{*}{ Compound } & \multirow{2}{*}{$\begin{array}{c}\text { Concentration } \\
\text { range, } \mathrm{mg} / \mathrm{L}\end{array}$} & \multicolumn{2}{|c|}{$\begin{array}{c}\text { Method with optimized } \\
\text { parameters }\end{array}$} & \multicolumn{2}{c|}{ GOST R 51786-2001 } \\
\cline { 3 - 6 } & & Slope & $\mathrm{R}^{2}$ & Slope & $\mathrm{R}^{2}$ \\
\hline Acetone & $1-1000$ & 58571 & 1.000 & 14179 & 0.999 \\
\hline Ethyl acetate & $1-1000$ & 47195 & 0.998 & 11055 & 0.996 \\
\hline Methanol (ppmV) & $1.26-1260$ & 46474 & 1.000 & 12224 & 0.999 \\
\hline 2-Butanol & $1-1000$ & 80698 & 1.000 & 20229 & 0.999 \\
\hline 1-Propanol & $1-1000$ & 77926 & 1.000 & 18928 & 0.999 \\
\hline iso-Butanol & $1-1000$ & 93912 & 1.000 & 21844 & 0.999 \\
\hline Isoamyl alcohol & $1-1000$ & 88064 & 1.000 & 21110 & 0.999 \\
\hline
\end{tabular}

Table 5 - Results of GC calibration according to optimized parameters and standard method GOST R 51786-2001 obtained on Agilent 6850 GC-FID located in Almaty Institute of Forensic Expertise

\begin{tabular}{|c|c|c|c|c|}
\hline \multirow{2}{*}{ Compound } & \multicolumn{2}{|c|}{ Optimized method } & \multicolumn{2}{c|}{ GOST R 51786-2001 } \\
\cline { 2 - 5 } & Slope & $\mathrm{R}^{2}$ & Slope & $\mathrm{R}^{2}$ \\
\hline Acetone & 0.5461 & 0.998 & 0.1665 & 0.999 \\
\hline Ethyl acetate & 0.0995 & 0.972 & 0.1161 & 0.995 \\
\hline Methanol & 0.5001 & 0.996 & 0.1218 & 0.999 \\
\hline 2-Butanol & 0.8574 & 0.997 & 0.2199 & 0.996 \\
\hline 1-Propanol & 0.8466 & 0.996 & 0.2186 & 0.999 \\
\hline iso-Butanol & 1.0409 & 0.997 & 0.2765 & 0.999 \\
\hline Isoamyl alcohol & 0.8785 & 0.998 & 0.2452 & 0.999 \\
\hline
\end{tabular}




\subsection{Application of the optimized method}

Application of the optimized method on real samples showed about 4-fold higher sensitivity compared to the standard method (Table 6). Highest concentrations were detected in sample 3 originated from Turkey. Such high concentrations are unusual for "pure" vodkas and may indicate presence of aroma additive. Therefore, this sample was not considered within the discussion of the results. Other samples have concentrations of impurities close to detection limits as was already mentioned in the Introduction.

Methanol was detected in all studied samples where it's concentrations varied from 5 (sample 8) to 723 (sample 9) ppmV. In samples 8 and 15, only methanol was detected in concentrations 5 and 374 ppmV. For detection of methanol in all samples, sensitivity of the standard method was enough. However, detection of other impurities in almost all samples was possible only using the optimized method.

1-Propanol often used as adulteration marker was detected in 10 samples. However, it's concentrations were very low reaching $3 \mathrm{mg} / \mathrm{L}$ in sample 25 (originated from the US). This sample also contained $3 \mathrm{mg} / \mathrm{L}$ of iso-butanol, which was not detected in all other samples. 1-Pentanol was only detected in samples 2 and 22.

As is clear from the obtained results, the optimized method having higher sensitivity compared to a standard one provides much more information about analyzed samples. This information may be used for disclosing adulterated samples and their origin.

Table 6 - Concentrations of impurities in studied vodka samples

\begin{tabular}{|c|c|c|c|c|c|c|c|}
\hline \multirow{3}{*}{$\#$} & Methanol & Acetone & Ethyl acetate & 2-Butanol & 1-Propanol & iso-Butanol & Isoamyl alcohol \\
\hline & \multicolumn{7}{|c|}{ Concentration } \\
\hline & ppmV & \multicolumn{6}{|c|}{$\mathrm{mg} / \mathrm{L}$} \\
\hline 1 & $46 \pm 1$ & $n / d$ & $\mathrm{n} / \mathrm{d}$ & $n / d$ & $\mathrm{n} / \mathrm{d}$ & $\mathrm{n} / \mathrm{d}$ & $\mathrm{n} / \mathrm{d}$ \\
\hline 2 & $118 \pm 1$ & $3 \pm 1$ & $\mathrm{n} / \mathrm{d}$ & $\mathrm{n} / \mathrm{d}$ & $\mathrm{n} / \mathrm{d}$ & $n / d$ & $\mathrm{n} / \mathrm{d}$ \\
\hline 3 & $155 \pm 2$ & $n / d$ & $44.0 \pm 0.5$ & $8.0 \pm 0.4$ & $90 \pm 1$ & $112 \pm 2$ & $266 \pm 2$ \\
\hline 4 & $22 \pm 1$ & $1.0 \pm 0.7$ & $n / d$ & $n / d$ & $n / d$ & $n / d$ & $n / d$ \\
\hline 5 & $7 \pm 1$ & $1.0 \pm 0.2$ & $n / d$ & $n / d$ & $\mathrm{n} / \mathrm{d}$ & $n / d$ & $n / d$ \\
\hline 6 & $14.0 \pm 0.5$ & $2.0 \pm 0.3$ & $n / d$ & $n / d$ & $n / d$ & $n / d$ & $n / d$ \\
\hline 7 & $11.0 \pm 0.4$ & $1.0 \pm 0.1$ & $n / d$ & $n / d$ & $n / d$ & $n / d$ & $\mathrm{n} / \mathrm{d}$ \\
\hline 8 & $5.0 \pm 0.1$ & $n / d$ & $\mathrm{n} / \mathrm{d}$ & $n / d$ & $\mathrm{n} / \mathrm{d}$ & $n / d$ & $\mathrm{n} / \mathrm{d}$ \\
\hline 9 & $723 \pm 4$ & $4.0 \pm 0.1$ & $n / d$ & $n / d$ & $1.0 \pm 0.1$ & $n / d$ & $30.0 \pm 0.1$ \\
\hline 10 & $432 \pm 3$ & $n / d$ & $n / d$ & $n / d$ & $0.6 \pm 0.1$ & $n / d$ & $n / d$ \\
\hline 11 & $115 \pm 1$ & $n / d$ & $\mathrm{n} / \mathrm{d}$ & $1.0 \pm 0.1$ & $\mathrm{n} / \mathrm{d}$ & $n / d$ & $4.0 \pm 0.1$ \\
\hline 12 & $100 \pm 1$ & $2.0 \pm 0.1$ & $\mathrm{n} / \mathrm{d}$ & $1.0 \pm 0.1$ & $n / d$ & $n / d$ & $0.5 \pm 0.1$ \\
\hline 13 & $495 \pm 5$ & $n / d$ & $\mathrm{n} / \mathrm{d}$ & $1.0 \pm 0.1$ & $n / d$ & $n / d$ & $2.0 \pm 0.1$ \\
\hline 14 & $422 \pm 7$ & $n / d$ & $n / d$ & $n / d$ & $n / d$ & $n / d$ & $n / d$ \\
\hline 15 & $374 \pm 2$ & $n / d$ & $n / d$ & $n / d$ & $n / d$ & $n / d$ & $n / d$ \\
\hline 16 & $205 \pm 0.5$ & $4.0 \pm 0.1$ & $n / d$ & $n / d$ & $n / d$ & $n / d$ & $7.0 \pm 0.4$ \\
\hline 17 & $80 \pm 1$ & $1.0 \pm 0.1$ & $\mathrm{n} / \mathrm{d}$ & $2.0 \pm 0.1$ & $0.4 \pm 0.1$ & $n / d$ & $2.0 \pm 0.2$ \\
\hline 18 & $36 \pm 1$ & $1.0 \pm 0.4$ & $n / d$ & $n / d$ & $n / d$ & $n / d$ & $n / d$ \\
\hline 19 & $42.0 \pm 0.1$ & $n / d$ & $n / d$ & $n / d$ & $0.5 \pm 0.1$ & $n / d$ & $n / d$ \\
\hline 20 & $375 \pm 4$ & $1.0 \pm 0.3$ & $n / d$ & $n / d$ & $0.4 \pm 0.1$ & $n / d$ & $n / d$ \\
\hline 21 & $6 \pm 1$ & $n / d$ & $n / d$ & $n / d$ & $0.4 \pm 0.1$ & $n / d$ & $n / d$ \\
\hline 22 & $14 \pm 1$ & $4.0 \pm 0.8$ & $\mathrm{n} / \mathrm{d}$ & $n / d$ & $n / d$ & $n / d$ & $\mathrm{n} / \mathrm{d}$ \\
\hline 23 & $9.0 \pm 0.5$ & $1.0 \pm 0.3$ & $n / d$ & $n / d$ & $0.8 \pm 0.1$ & $n / d$ & $n / d$ \\
\hline 24 & $5.0 \pm 0.6$ & $\mathrm{n} / \mathrm{d}$ & $1 \pm 0.3$ & $\mathrm{n} / \mathrm{d}$ & $0.5 \pm 0.1$ & $\mathrm{n} / \mathrm{d}$ & $\mathrm{n} / \mathrm{d}$ \\
\hline 25 & $415 \pm 4$ & $n / d$ & $5 \pm 0.1$ & $n / d$ & $3 \pm 0.1$ & $3.0 \pm 0.1$ & $3.0 \pm 0.2$ \\
\hline 26 & $9.0 \pm 0.3$ & $n / d$ & $n / d$ & $n / d$ & $n / d$ & $n / d$ & $n / d$ \\
\hline
\end{tabular}




\section{Conclusion}

Thus, GC-FID method was optimized for sensitive determination of vodka impurities. The main parameters of GC and FID, which can influence on sensitivity of method determination of impurities were optimized: split ratio, inlet temperature, oven temperature, flow rates of make-up gas, air and hydrogen. The split ratio 10:1, the inlet temperature $120^{\circ} \mathrm{C}$, initial oven temperature $60^{\circ} \mathrm{C}$, make-up flow rate $50 \mathrm{~mL} / \mathrm{min}$, air flow $400 \mathrm{~mL} / \mathrm{min}$ and hydrogen flow rate $40 \mathrm{~mL} / \mathrm{min}$ were selected as optimal.

Obtained calibration plots are linear in concentration ranges $1-1000 \mathrm{mg} / \mathrm{L}$ with approximation coefficients $R^{2}>0.99$. Compared to standard GOST R 51786-2001 and GOST R 51698-2000 methods, slope factors are about 4 times higher when optimized method is used proving its higher sensitivity.
Application of the optimized method for analysis of real samples confirmed it's higher sensitivity. For detection of methanol in all samples, sensitivity of the standard method was enough. However, detection of other impurities in almost all samples was possible only using the optimized method. Due to the higher sensitivity of the optimized method, it can be recommended for disclosing adulterated samples in forensic laboratories.

\section{Acknowledgement}

This work was conducted under International Science and Technology (ISTC) project K-1983 "Improvement of forensic methodology for discovery of adulterated alcoholic beverages" funded by the US Department of State.

\section{References}

1 Who drinks most vodka, gin, whisky and rum? // "The Daily chart" Internet newspaper. - 2013. - 17 June. http:// www.economist.com/blogs/graphicdetail/2013/06/daily-chart-9

2 Kazakhstan tooks the fifth place by the number of drunk vodka [Po kolichestvu vipitoy vodka Kazakhstan vishel na pyatoe mesto] // "Radio Azattyk" Internet newspaper. - 2013. - 24 June. http://rus.azattyq.org/content/reiting-stranpo-urovnyu-potrebleniya-alkogolya/25026039.html. (In Russian)

3 The Law of the Republic of Kazakhstan 16.07.1999 No. 429-I "On state regulation of production and turnover of ethyl alcohol and alcoholic beverages".

4 GOST R 51786-2001. Vodka and ethanol from food raw material. Gas chromatographic method for determination of authenticity [GOST. Vodka i spirt etiloviy iz pishevogo siriya. Gazokhromatograficheskiy metod opredeleniya podlinnosti]. Moscow, Russia, 2001. (In Russian)

5 GOST R 51698-2000. Vodka and ethanol from food raw material. Gas-chromatographic express-method for determination of toxic microadmixtures content [GOST. Vodka i spirt etiloviy iz pishevogo siriya. Gazokhromatograficheskiy ekspress-metod opredeleniya soderjaniya toksichnikh microprimisey]. Moscow, Russia, 2000. (In Russian)

6 Fedyanin A.A., Prihodko A.A., Habalova O.S. Forensic investigation of microquantities of the factory-produced alcoholic beverages by capillary gas chromatography method for their differentiation by type: Tutorial. - Gorkiy: CRLF, 1977. (In Russian)

7 Fedyanin A.A., Prihodko A.A., Habalova O.S. Forensic investigation of microquantities of unknown alcoholic beverages by capillary gas chromatography for their differentiation based on conditions of production (factory, domestic): Tutorial. - Gorkiy: CRLF, 1977. (In Russian)

8 Moskvitin N.N., Chuprakov I.A., Petranek G., Slavichek I. The use of gas-liquid chromatography in forensic investigations. Research Institute of Ministry of Internal Affairs of the USSR. - Moscow: RIMEM typography, 1971. (In Russian)

9 Lachenmeier D.W., Sohnius E.-M. The role of acetaldehyde outside ethanol metabolism in the carcinogenicity of alcoholic beverages: Evidence from a large chemical survey // Food and Chemical Toxicology. - 2008.- Vol.46. - P.29032911.

10 Kanteres F., Rehm J., Lachenmeier D.W. Artisanal alcohol production in Mayan Guatemala: Chemical safety evaluation with special regard to acetaldehyde contamination // Science of the Total Environment. - 2009. - Vol.407. P.5861-5868.

11 Lachenmeier D.W. Rapid quality control of spirit drinks and beer using multivariate data analysis of Fourier transform infrared spectra // Food Chemistry. - 2007. - Vol.101. - P.825-832.

12 Savchuk S.A., Kolesov G.M. Chromatographic techniques in the quality control of cognacs and cognac spirits // Journal of Analytical Chemistry. - 2005. - Vol.60, №8. - P.752-771. 


\section{References}

1 "The Daily chart" Internet newspaper, 17 June (2013) Who drinks most vodka, gin, whisky and rum? http://www. economist.com/blogs/graphicdetail/2013/06/daily-chart-9

2 "Radio Azattyk" Internet newspaper, 24 June (2013) Kazakhstan tooks the fifth place by the number of drunk vodka [Po kolichestvu vipitoy vodka Kazakhstan vishel na pyatoe mesto]. http://rus.azattyq.org/content/reiting-stran-pourovnyu-potrebleniya-alkogolya/25026039.html. (In Russian)

3 The Law of the Republic of Kazakhstan 16.07.1999 No. 429-I “On state regulation of production and turnover of ethyl alcohol and alcoholic beverages"

4 GOST R 51786-2001. Vodka and ethanol from food raw material. Gas chromatographic method for determination of authenticity [GOST. Vodka i spirt etiloviy iz pishevogo siriya. Gazokhromatograficheskiy metod opredeleniya podlinnosti]. Moscow, Russia, 2001. (In Russian)

5 GOST R 51698-2000. Vodka and ethanol from food raw material. Gas-chromatographic express-method for determination of toxic microadmixtures content [GOST. Vodka i spirt etiloviy iz pishevogo siriya. Gazokhromatograficheskiy ekspress-metod opredeleniya soderjaniya toksichnikh microprimisey]. Moscow, Russia, 2000. (In Russian)

6 Fedyanin AA, Prihodko AA, Habalova OS (1977) Forensic investigation of microquantities of the factory-produced alcoholic beverages by capillary gas chromatography method for their differentiation by type: Tutorial. CRLF, Gorkiy, Russia. (In Russian)

7 Fedyanin AA, Prihodko AA, Habalova OS (1977) Forensic investigation of microquantities of unknown alcoholic beverages by capillary gas chromatography for their differentiation based on conditions of production (factory, domestic): Tutorial. CRLF, Gorkiy, Russia. (In Russian)

8 Moskvitin NN, Chuprakov IA, Petranek G, Slavichek I (1971) The use of gas-liquid chromatography in forensic investigations. Research Institute of Ministry of Internal Affairs of the USSR. RIMEM typography, Moscow, Russia. (In Russian)

9 Lachenmeier DW, Sohnius EM (2008) Food and Chem Toxicol 46:2903-2911. http://dx.doi.org/10.1016/j. fct.2008.05.034

10 Kanteres F, Rehm J, Lachenmeier DW (2009) Sci Total Environ 407:5861-5868. http://dx.doi.org/10.1016/j. scitotenv.2009.08.012

11 Lachenmeier DW (2007) Food Chem 101:825-832. http://dx.doi.org/10.1016/j.foodchem.2005.12.032

12 Savchuk SA, Kolesov GM (2005) J Anal Chem 60:752-771. http://dx.doi.org/10.1007/s10809-005-0176-9 